\title{
Heavy Metals in Soil and Salad in the Proximity of Historical Ferroalloy Emission
}

\author{
Roberta Ferri ${ }^{1}$, Filippo Donna', Donald R. Smith ${ }^{2}$, Stefano Guazzetti ${ }^{3}$, Annalisa Zacco ${ }^{4}$, Luigi Rizzo ${ }^{4}$, \\ Elza Bontempi ${ }^{4}$, Neil J. Zimmerman ${ }^{5}$, Roberto G. Lucchini ${ }^{1,6}$
}

${ }^{1}$ Department of Experimental and Applied Medicine, University of Brescia, Brescia, Italy; ${ }^{2}$ Microbiology and Environmental Toxicology, University of California, Santa Cruz, USA; ${ }^{3}$ Public Health Service, Reggio Emilia, Italy; ${ }^{4}$ INSTM and Chemistry for Technologies Laboratory, University of Brescia, Brescia, Italy; ${ }^{5}$ School of Health Sciences, Purdue University, West Lafayette, USA; ${ }^{6}$ Department of Preventive Medicine, Mount Sinai School of Medicine, New York, USA.

Email: filippo.donna@gmail.com

Received March $5^{\text {th }}, 2012$; revised April $5^{\text {th }}, 2012$; accepted May $3^{\text {rd }}, 2012$

\begin{abstract}
Emissions of manganese $(\mathrm{Mn})$, lead $(\mathrm{Pb})$, iron $(\mathrm{Fe})$, zinc $(\mathrm{Zn})$, copper $(\mathrm{Cu})$ from ferro-alloy operations has taken place in Valcamonica, a pre-Alp valley in the province of Brescia, Italy, for about a century until 2001. Metal concentrations were measured in the soil of local home gardens and in the cultivated vegetables. Soil analysis was carried out using a portable X-Ray Fluorescence (XRF) spectrometer in both surface soil and at $10 \mathrm{~cm}$ depth. A subset of soil samples $(\mathrm{n}=$ 23) additionally was analysed using the modified BCR sequential extraction method and ICP-OES for intercalibration with XRF (XRF Mn $=1.33 *$ total OES Mn $-71.8 ; \mathrm{R}=0.830, \mathrm{p}<0.0001$ ). Samples of salads (Lactuca sativa and Chichorium spp.) were analyzed with a Total Reflection X-Ray Fluorescence (TXRF) technique. Vegetable and soil metal measurements were performed in 59 home gardens of Valcamonica, and compared with 23 gardens from the Garda Lake reference area. Results indicate significantly higher levels of soil Mn (median 986 ppm vs $416 \mathrm{ppm}$ ), $\mathrm{Pb}$ (median $46.1 \mathrm{ppm}$ vs $30.2 \mathrm{ppm}$ ), Fe (median 19,800 ppm vs 13,100 ppm) in the Valcamonica compared to the reference area. Surface soil levels of all metals were significantly higher in surface soil compared to deeper soil, consistent with atmospheric deposition. Significantly higher levels of metals were shown also in lettuce from Valcamonica for $\mathrm{Mn}$ (median $53.6 \mathrm{ppm}$ vs 30.2) and Fe (median 153 vs 118). Metals in Chichorium spp. did not differ between the two areas. Surface soil metal levels declined with increasing distance from the closest ferroalloy plant, consistent with plant emissions as the source of elevated soil metal levels. A correlation between Mn concentrations in soil and lettuce was also observed. These data show that historic ferroalloy plant activity, which ended nearly a decade before this study, has contributed to the persistence of increased Mn levels in locally grown vegetables. Further research is needed to assess whether this increase can lead to adverse effects in humans and plants especially for $\mathrm{Mn}$, an essential element that can be toxic in humans when exceeding the homeostatic ranges.
\end{abstract}

Keywords: Heavy Metals; Ferroalloy Plant; Soil; Vegetables; XRF; ICP-OES

\section{Introduction}

Metal contamination of the environment raises concern for the possible impact on human health, and the occurrence of heavy metals in soils, of both natural and anthropogenic origin, is well-recognized as a potentially important source of human exposure [1,2]. Once contaminated, soils typically remain contaminated for protracted periods of time because of sorption of metals onto soil particles and limited mobility. Data have shown that increased soil levels of metals like chromium (Cr), copper $(\mathrm{Cu})$, lead $(\mathrm{Pb})$, manganese $(\mathrm{Mn})$, nickel $(\mathrm{Ni})$ [3], and arsenic (As) [4] are associated with neurodevelopmental effects in children, presumably due to increased metal exposure from hand-to-mouth behavior and mouthing of hands and objects contaminated with soil particles.

Where metals in soil are increased by anthropogenic disposal and emission, the measure of metal concentrations provide useful information on potential human cumulative exposure. Estimates of cumulative exposure are intended to integrate a variety of different processes affecting exposure over extended time periods. Lifetime cumulative exposure is particularly relevant for evaluating health risks from heavy metals, since it may help predict cumulative neurotoxic effects. Prolonged metal exposure spanning neurodevelopmental periods may also increase the risk of neurodegenerative conditions in old age [3]. Metals are naturally present in soil in relation to 
the soil parent material, and may be modified by both natural (e.g., flooding, volcanic eruptions, forest fires) and anthropogenic processes. Anthropogenic processes recognized as potential sources of soil contamination with heavy metals include: 1) agricultural activities with the use of metal-containing fertilizers, pesticides, sewage sludge, and irrigation water; 2) emissions from energy and fuel production activities; 3) mining and smelting operations, such as tailing, smelting, refining and transportation; 4) vehicle traffic and combustion of petroleum fuels containing metal additives; 5) emissions from waste incineration; and 6) metal recycling operations like scrap melting [5].

The accumulation of heavy metals in agricultural soils, including home vegetable gardens may be of particular concern since consumption of vegetables grown in metal contaminated soils may pose health risks for the population residing in these areas [6,7]. While essential trace metals such as $\mathrm{Cu}, \mathrm{Cr}, \mathrm{Ni}, \mathrm{Mn}$, fluorine (F), molybdenum (Mo), selenium (Se) and zinc ( $\mathrm{Zn}$ ) are necessary for plant growth and/or human nutrition at low levels, they may also be toxic to both animals and humans at high exposures. Other trace elements, for example $\mathrm{As}, \mathrm{Pb}$, cadmium $(\mathrm{Cd})$, and mercury $(\mathrm{Hg})$, may also inadvertently enter the food chain and pose health risks to humans and animals [8].

The uptake of metals from soil into plants is affected by soil chemistry, metal speciation (i.e., inorganic and organic complexation), and molecular transport and storage processes in plants [9]. These processes can be summarized in terms of metal bioavailability, which reflects the fraction of a metal in soil that is available for uptake into a plant. Some plants, such as Thlaspi rotundifolium, Brassica juncea, Festuca arundinacea, Helianthus annuus, and Medicago sativa can hyper-accumulate metal ions because of specialized mechanisms of absorption and transport of internal ions. These plants can tolerate high concentrations of toxic metals in soil, and may also have potential for phyto-remediation in contaminated soils $[9,10]$. However, edible plants grown in contaminated soils may also accumulate elevated levels of metals that may, when consumed, increase exposures to humans. For example, crops like lettuce, spinach, carrot, radish, zucchini have been shown to accumulate increased levels of potentially toxic metals such as $\mathrm{Mn}, \mathrm{Pb}, \mathrm{Fe}, \mathrm{Zn}, \mathrm{Cu}$, etc. when grown in soils contaminated from sewage sludge [11,12], mine wastes [13], and application of livestock and poultry manures [14].

The ferroalloy industry produces various metal alloys used in iron smelters, resulting in increased atmospheric release and deposition of potentially toxic metals like $\mathrm{Mn}$, $\mathrm{Pb}, \mathrm{Fe}, \mathrm{Zn}, \mathrm{Cu}$, etc. Few data are available on soil accumulation of these metals from ferroalloy and smelting activity, the human absorption through locally cultivated vegetables, and the potential impacts on human health. Manganese raises particular concern because of neurotoxic effects resembling Parkinson's Disease that have been observed in exposed workers to airborne concentrations above $1 \mathrm{mg} / \mathrm{m}^{3}$ [15]. An epidemiological study in the province of Brescia, Italy, showed an increased prevalence of parkinsonian disturbances in the vicinities of ferro-manganese plants in the area of Valcamonica [16]. The Standardized Morbidity Ratios were positively associated with the Mn levels in deposited dust, originating from atmospheric deposition from ferroalloy plant emissions. Levels of $\mathrm{Pb}, \mathrm{Fe}$, and $\mathrm{Zn}$ were also elevated in deposited dust in the same area [17].

Here, we investigated metal concentrations in soil and locally cultivated edible plants in the Province of Brescia, Italy, in locales with prolonged histories of ferroalloy plant activity. This assessment was part of an extended epidemiological study on health outcomes as a function of metal exposure in three different age groups of residents in the area of Valcamonica: adolescents, elderly and pregnant mothers. The region of Garda Lake was identified as local reference area because of the absence of major industrial emissions, and based on lower levels of metals in settled dust [17]. The specific aims of this study were to determine: 1) if the levels of $\mathrm{Mn}$ and other metals in the soil and vegetables from home gardens in Valcamonica differed from those located in the reference area; 2 ) if the levels of metals in soil and vegetables from the home gardens in Valcamonica were inversely related to the distance from the point emitting sources; and 3) if there was a correlation between the concentration of Mn and other metals in soil and vegetables from the same home gardens. This study is part of a large on-going investigation in which we have conducted detailed exposure assessment of metal concentrations in airborne particles, deposited dust, soil, diet and several biomarkers of resident children, in addition to a comprehensive assessment [18] of neurobehavioral motor and cognitive functions in children as potential health impacts of metal exposure.

\section{Materials and Methods}

Concentrations of $\mathrm{Mn}, \mathrm{Fe}, \mathrm{Zn}, \mathrm{Cu}$ were measured in cultivated edible plants and in the adjacent soils from local vegetable gardens of subjects recruited into the larger epidemiological study noted above. Subjects $(n=82)$ were selected for the present study from the larger cohort ( $n=322$ subjects) based on response to a dietary survey indicating that their families cultivated and consumed home grown vegetables. Subjects were provided verbal and written description of the study and requirements, and in turn provided written consent to participate as approved by the Ethical Committee of the Public Health 


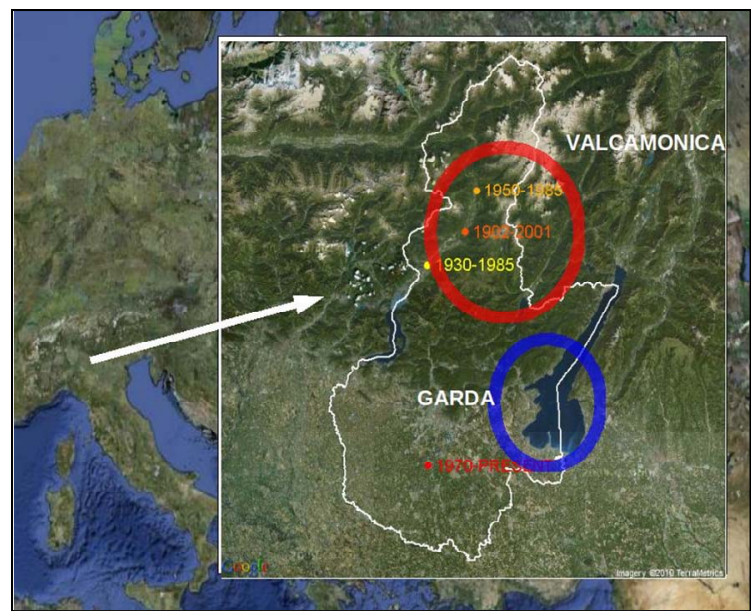

Figure 1. Study location: the target area of Valcamonica, and the reference area of Garda Lake in the province of Brescia, Italy, with the location of the previously and currently operating ferroalloy plants.

Agency of Brescia, Italy. Recruitment and enrolment procedures of participants are described in a separate publication [19].

\section{Study Area}

Valcamonica is a valley of the Italian pre-Alps, located in the province of Brescia that has been the operational site of three 85 ferroalloy plants for about a century until 2001. Ferroalloy plants were located from South to North in the villages of Darfo (operational period 1930-1995), Breno (operational period 1902-2001), and Sellero (operational period 1950-1985). The reference area of Garda Lake has no history of 90 metallurgic industry activity (Figure 1). More detailed information on the study sites and the relative concentration of metals in outdoor settled dust have been previously published [16,17]. Vegetable and soil metal measurements were performed in 82 home vegetable gardens, 59 of them 95 were located in the Valcamonica region and 23 in the reference area of Garda Lake.

\section{Soil Measurement}

The metal content in the soil of the vegetable gardens was directly analyzed by using a portable instrument based on X-Ray Fluorescence (XRF) (Thermo Scientific Niton, model XLt) equipped with GPS geo-referencing capability. The instrument was kept steadily on top of the soil surface, with an $\mathrm{x}$-ray exposure and x-ray fluorescence signal collection time of approximately $100 \mathrm{sec}-$ onds. One to four randomly distributed readings of surface soil, depending on the size of the garden, were taken per garden to obtain an average value for each garden. In addition, one representative sub-surface soil reading was taken from each garden after removing surface soil to a depth of $10 \mathrm{~cm}$. A GPS reader yielded geo-referencing of each measurement to calculate the distance of each point from the ferroalloy plant exposure point source; i.e., GPS coordinates for each measurement were used to calculate an average distance of each garden from the ferroalloy plant.

Soil $\mathrm{pH}$ was determined in a 1:2.5 soil/water suspension to allow more accurate comparisons among the gardens. A pH meter fitted with a glass electrode was used according to the Italian official methodology [20].

In order to intercalibrate the portable XRF soil metal measurements, and to determine the association between total soil metal levels and the chemically labile fraction of metals in soil, a sub-set of 23 randomly selected soil samples were analyzed by ICP-OES after sequential extraction using a modified BCR procedure [21]. Briefly, surface soil samples $(\sim 100 \mathrm{~g})$ were collected, dried in an oven $\left(65^{\circ} \mathrm{C}\right)$ for $24 \mathrm{~h}$ to a constant dry weight, sieved to $150 \mu \mathrm{m}$, and $\mathrm{a} \sim 1 \mathrm{~g} \pm 10 \%$ sub-sample taken for sequential extraction and analyses. Soil samples were extracted first with $0.11 \mathrm{~mol} \cdot \mathrm{L}^{-1}$ acetic acid (fraction 1 , exchangeable and weak acid soluble metals), second with $0.5 \mathrm{~mol}$ $\mathrm{L}^{-1}$ hydroxylammonium chloride (fraction 2, reducible metals), third with repeated extraction with $\mathrm{H}_{2} \mathrm{O}_{2}$ (fraction 3, oxidizable metals), and finally with $7.5 \mathrm{~N} \mathrm{HNO}_{3}$ (fraction 4, remaining strong acid extractable metals). The concentrations of $\mathrm{Cu}, \mathrm{Fe}, \mathrm{Mn}, \mathrm{Zn}$ in the extracts were determined by inductively coupled plasma-optical emission spectrometry (ICP-OES) using a Perkin-Elmer Optima 4300 DV Series instrument. Parallel analyses of standard reference material BCR 483 (sewage sludge amended soil certified by Community Bureau of Reference) was used to evaluate extraction efficiency and analytical accuracy $[22,23]$. The analytical detection limit for $\mathrm{Cu} \mathrm{Fe}, \mathrm{Mn}$, and $\mathrm{Zn}$ were 0.01, 0.68, 0.025, and 0.020 $\mathrm{ug} / \mathrm{mL}$ for the analyzed extract, respectively. The analytical reproducibility averaged $9 \%$ (RSD) based on triplicate processing and analyses of selected soil samples. Analytical accuracy averaged 88\% (range 80\% - 107\%) of expected values in BCR fractions 1 - 3 for certified metals, based on repeated triplicate processing and analyses of SRM BCR 483.

\section{Vegetable Sampling and Analysis}

Two kinds of the most commonly grown leafy vegetables in local gardens were selected: lettuce (Lactuca sativa) and chicory (Chichorium spp., also called Radicchio). Throughout the time of sample collection, which occurred from April to October, vegetables were collected at a normal harvestable and edible stage and were representative of the crop. Three vegetable leaves were collected from 3 plants into polyethylene bags and stored at $4^{\circ} \mathrm{C}$ for 24 hours in the laboratory before processing for 
metal concentration analysis.

The edible parts of each vegetable sample were carefully washed with MQ water to eliminate any possible external contamination due to superficial airborne-deposited particles or residual surface dirt. Then they were air-dried in a fume hood at room temperature (approximately $25^{\circ} \mathrm{C}$ for $24 \mathrm{~h}$ ).

The three leaves of each plant were ground and a quantity of $10 \mathrm{mg}$ was taken from the mixture and digested in a polyvinyl-fluoride test-tube with $1 \mathrm{ml}$ of concentrated nitric acid for 48 hours in a fume hood at room temperature.

Metal levels in plant digestated were analyzed at the Laboratory of Chemistry for Technology, University of Brescia, with a spectrometer based on Total Reflection X-Ray Fluorescence (TXRF) (Bruker S2 Picofox, air cooled, Mo tube, Silicon-Drift Detector, operating values $50 \mathrm{kV}$ and $1000 \mu \mathrm{A}$ ), using an acquisition time of 600 seconds. The concentration of $\mathrm{Mn}, \mathrm{Zn}, \mathrm{Cu}, \mathrm{Fe}$, and $\mathrm{Pb}$ was determined on the basis of the known content of $\mathrm{Ga}$, which was used as an internal standard. TXRF is a non destructive methodology that provides efficient multielemental identification and quantification of elements in samples for human environmental exposure assessment. TXRF is both rapid and sensitive (to the ppb level), and is not affected by complex sample matrices [24]. Detection/quantitation limit, accuracy, and precision of Picofox have been reported in literature [25]. A significant correlation has been demonstrated between the TXRF techniques and the other standard methods for metal analysis such as AAS and ICPMS [26].

\section{Statistical Analysis}

Since most of the metal concentrations in plants and soils showed a skewed distribution, we used empirical quartiles to summarize the data and non-parametric statistics (Wilcoxon Mann-Whitney U Test) were applied to compare the results of soil and vegetable measures between the exposed and reference areas. Wilcoxon signed rank test was used to compare surface soil and sub-surface soil (10 cm depth) metal levels. For the same reason Kendall's Tau was used to measure the association between the concentration of metals in soil and in vegetables. Statistical analyses and graphics were made with R 2.10.1 [27].

\section{Results}

\subsection{Inter-Comparison between XRF and ICP-OES}

Analyses of a subset of soil samples $(n=23)$ from the Valcamonica and Garda Lake study sites were performed using a BCR sequential extraction method and ICP-OES analyses, in order to 1) validate the portable field XRF analyses that were used at all study sites, and 2) to evaluate the relationship between total soil metal levels and the chemically labile fraction of metals in soil (defined here as the sum of extractable metals in BCR fractions 1 +2 ). While the sequential BCR extraction method does not directly indicate bioavailability of metals in soil, metals that are chemically labile would be expected to reflect increased bioavailability as well.

A significant association was observed between both the near total BCR extractable metal levels (sum fractions $1-4)$ and the chemically labile metals fractions (BCR fractions $1+2$ ) with soil metal levels measured by XRF. For example, near total Mn levels measured with the BCR and ICP-OES were highly significantly correlated with Mn levels measured by XRF (XRF Mn = $1.33 *$ OES Mn $-71.8, \mathrm{R}=0.830, \mathrm{p}<0.0001)$. Similarly, chemically labile Mn levels measured with the BCR and ICP-OES (BCR fractions $1+2$ ) were also significantly correlated with Mn levels measured by XRF (XRF Mn = $1.43 *$ OES Mn $-14.7, \mathrm{R}=0.826, \mathrm{p}<0.0001)$. Importantly, a highly significant relationship resulted also between near total soil Mn (sum fractions $1-4$ ) and the chemically labile $\mathrm{Mn}$ in soil (fractions $1+2$ ), as determined by the BCR sequential extraction method and ICP-OES (labile $\mathrm{Mn}=0.9141 *$ total $\mathrm{Mn}-30.86, \mathrm{R}=$ 0.990, $\mathrm{p}<0.0001)$.

Highly significant relationships exist between soil measurements by ICP-OES and XRF (both in ppm units) for the other metals as well: for Fe near total BCR and OES vs XRF, XRF Fe $=2.36^{*} \mathrm{OES} \mathrm{Fe}+5360, \mathrm{R}=0.772$, $\mathrm{p}<0.0001$; for labile Fe by OES (BCR F1 + F2) vs XRF, $\mathrm{XRF} F \mathrm{Fe}=13.8 *$ OES Fe $+10660, \mathrm{R}=0.772, \mathrm{p}<0.0001$; for near total $\mathrm{Fe}$ by OES vs labile $\mathrm{Fe}$ by OES, labile $\mathrm{Fe}=$ $0.145 *$ total $\mathrm{Fe}-257, \mathrm{R}=0.876, \mathrm{p}<0.0001$. For $\mathrm{Zn}$ near total BCR and OES vs XRF, XRF Zn $=1.056^{*} \mathrm{OES} \mathrm{Zn+}$ 25.3, $\mathrm{R}=0.902, \mathrm{p}<0.0001$; for labile $\mathrm{Zn}$ by OES (BCR $\mathrm{F} 1+\mathrm{F} 2)$ vs XRF, XRF $\mathrm{Zn}=1.25^{*} \mathrm{OES} \mathrm{Zn}+60.5, \mathrm{R}=$ $0.843, \mathrm{p}<0.0001$; for near total $\mathrm{Zn}$ by OES vs labile $\mathrm{Zn}$ by OES, labile $\mathrm{Zn}=0.773 *$ total $\mathrm{Zn}-17.9, \mathrm{R}=0.977$, $\mathrm{p}$ $<0.0001$. For $\mathrm{Pb}$ near total BCR and OES vs XRF, XRF $\mathrm{Pb}=0.893 * \mathrm{OES} \mathrm{Pb}+2.11, \mathrm{R}=0.774, \mathrm{p}<0.0001$; for labile $\mathrm{Pb}$ by OES (BCR F1 + F2) vs XRF, XRF Pb = $1.52 * \mathrm{OES} \mathrm{Pb}+5.24, \mathrm{R}=0.719, \mathrm{p}<0.0001$; for near total $\mathrm{Pb}$ by $\mathrm{OES}$ vs labile $\mathrm{Pb}$ by OES, labile $\mathrm{Pb}=0.487^{*}$ total $\mathrm{Pb}+2.86, \mathrm{R}=0.894, \mathrm{p}<0.0001$.

\subsection{Comparison of Metals in Soil and Vegetables in the Two Areas}

Table 1 reports the results of soil measurements. Average metal concentrations were significantly higher in Valcamonica compared to Garda Lake for Mn ( $\mathrm{p}<$ $0.0001), \mathrm{Pb}(\mathrm{p}=0.04)$, and $\mathrm{Fe}(\mathrm{p}<0.0001)$ in surface soil, and for $\mathrm{Mn}(\mathrm{p}=0.0002), \mathrm{Pb}(\mathrm{p}=0.03)$, and $\mathrm{Fe}(\mathrm{p}<$ 
Table 1. Concentrations of metals on surface and $10 \mathrm{~cm}$ depth soil from the vegetable gardens of Valcamonica $(\mathrm{n}=64)$ and Garda Lake $(\mathbf{n}=\mathbf{2 0})$.

\begin{tabular}{|c|c|c|c|c|c|c|c|c|c|c|c|}
\hline & \multicolumn{5}{|c|}{ Surface (a) } & \multicolumn{5}{|c|}{ Depth (b) } & \multirow[b]{3}{*}{ p value ${ }^{*}$} \\
\hline & \multicolumn{2}{|c|}{ Valcamonica (c) } & \multicolumn{2}{|c|}{ Garda Lake (d) } & \multirow[b]{2}{*}{ p Value } & \multicolumn{2}{|c|}{ Valcamonica } & \multicolumn{2}{|c|}{ Garda Lake } & \multirow[b]{2}{*}{$\mathrm{p}$ value } & \\
\hline & Median & Interquartile range & Median & $\begin{array}{l}\text { Interquartile } \\
\text { range }\end{array}$ & & Median & Interquartile range & Median & $\begin{array}{c}\text { Interquartile } \\
\text { range }\end{array}$ & & \\
\hline Mn (ppm) & 986.29 & $\begin{array}{c}(803.87 \\
-1168.04)\end{array}$ & 415.76 & $\begin{array}{c}(397.48 \\
-483.86)\end{array}$ & $<0.0001$ & 715.02 & $\begin{array}{c}(582.72 \\
-792.12)\end{array}$ & 367 & $\begin{array}{c}(300.44 \\
-439.56)\end{array}$ & 0.0002 & 0.0039 \\
\hline $\mathrm{Fe}(\mathrm{ppm})$ & 19781.99 & $\begin{array}{c}(15802.84 \\
-23746.51)\end{array}$ & 13088.14 & $\begin{array}{c}(9953.98 \\
-14449.7)\end{array}$ & $<0.0001$ & 15296.99 & $\begin{array}{c}(13524.31 \\
-21142.72)\end{array}$ & 11199.54 & $\begin{array}{c}(8552.53 \\
-12098.26)\end{array}$ & 0.0004 & $<0.0001$ \\
\hline $\mathrm{Zn}(\mathrm{ppm})$ & 167.01 & $\begin{array}{c}(137.28 \\
-196.89)\end{array}$ & 128.38 & $\begin{array}{c}(85.9 \\
-198.2)\end{array}$ & 0.5016 & 155.61 & $\begin{array}{l}(108.44 \\
190.48)\end{array}$ & 144.57 & $\begin{array}{c}(83.38 \\
-173.59)\end{array}$ & 0.5799 & 0.0695 \\
\hline $\mathrm{Cu}(\mathrm{ppm})$ & 48.98 & $\begin{array}{c}(36.02 \\
-99.22)\end{array}$ & 85.45 & $\begin{array}{c}(58.28 \\
-91.13)\end{array}$ & 0.2204 & 46.43 & $\begin{array}{c}(29.36 \\
-102.46)\end{array}$ & 72.06 & $\begin{array}{c}(53.86 \\
-88.44)\end{array}$ & 0.2542 & 0.0060 \\
\hline
\end{tabular}

§(c vs d), Wilcoxon Mann Whitney rank sum test. * (a vs b), Wilcoxon signed rank test.

$0.0001)$ at $10 \mathrm{~cm}$ soil depth. Levels in surface soil were also significantly higher than in deeper soil for $\mathrm{Mn}(\mathrm{p}=$ $0.004), \mathrm{Pb}(\mathrm{p}=0.004), \mathrm{Fe}(\mathrm{p}<0.0001)$ in both Valcamonica and Garda lake areas considered separately.

Moreover, differences between concentrations of $\mathrm{Mn}$ in paired surface and sub-surface soil samples were higher in Valcamonica compared to the Garda Lake, and they increased significantly as a function of the average metal concentration in surface soil, as shown by a Tukey mean-difference plot (Figure 2; the dotted line shows the mean difference between the surface soil and the deeper soil measures, about $107 \mathrm{ppm}$ ). Although not reaching statistical significance, $\mathrm{Zn}$ levels were higher in the surface and deeper soil of Valcamonica compared to the Garda Lake, and with border line significance $(p=0.07)$ in surface soil than in deeper soil of Valcamonica, as compared to the Garda Lake. Also, while not reaching statistical significance, $\mathrm{Cu}$ levels were higher instead in the surface and deeper soil of Garda Lake compared to Valcamonica, and they were significantly higher $(\mathrm{p}=$ 0.006) in surface soil than in deeper soil in the Garda Lake, as compared to Valcamonica. The average values of $\mathrm{pH}$ in soil did not differ significantly between the gardens of Valcamonica $(\mathrm{pH}$ 7.2) and the Garda Lake $(\mathrm{pH}$ 7.5).

Tables 2 and 3 report the results of trace element levels in lettuce and chicory grown in the home gardens of Valcamonica and the Garda Lake. A statistically significant increase was observed in lettuce Mn levels from Valcamonica compared to the Garda Lake $(\mathrm{p}=0.04)$, and a borderline increase existed for $\mathrm{Fe}(\mathrm{p}=0.08)$ concentrations. No significant differences were observed for metal concentrations in chicory grown in the two study areas. The concentration of $\mathrm{Pb}$ in both vegetable types was lower than the procedural detection limit $0.004 \mu \mathrm{g} \mathrm{Pb} / \mathrm{g}$ for salad material [23]. Although not reaching statistical significance, $\mathrm{Zn}$ was higher in both lettuce and chicory grown in Valcamonica compared to the Garda Lake site. In contrast, and following patterns in soil $\mathrm{Cu}$, the concentration of $\mathrm{Cu}$ was significantly higher in chicory grown in the Garda Lake $(p=0.05)$, and trended to be higher in lettuce grown in the Garda Lake compared to Valcamonica, although differences did not reach statistical significance $(\mathrm{p}=0.22)$.

\subsection{Metal Concentrations in Relation to the Distance from Point Sources}

The geographical distributions of surface soil Mn levels in Valcamonica and the Garda Lake as a function of the distance from the closest ferroalloy plant (the presumed point source of elevated soil metal levels) are shown in Figure 4. Generally, there is a significant reduction in the surface soil concentration of Mn with increasing distance away from the ferroalloy plants in the Valcamonica, consistent with the hypothesis that these industrial plants are important sources of metal emissions to the surrounding local environment.

\subsection{Relationship between Metals in Soil and in Vegetables}

Mn in surface soil and lettuce were found to be significantly and positively associated with a one-tailed Tau test (Kendall's Tau $=0.333, \mathrm{p}=0.013$ ), while no association was found between the soil and the chicory Mn concentrations (Kendall's Tau $=0.495, \mathrm{p}=0.72$ ). Figure 3 shows the relationships between surface soil $\mathrm{Mn}$ and $\mathrm{Mn}$ in lettuce and chicory are shown in the Trellis graph. A local regression (loess) line has been added to the graph that reveals the shape of the relationships. 

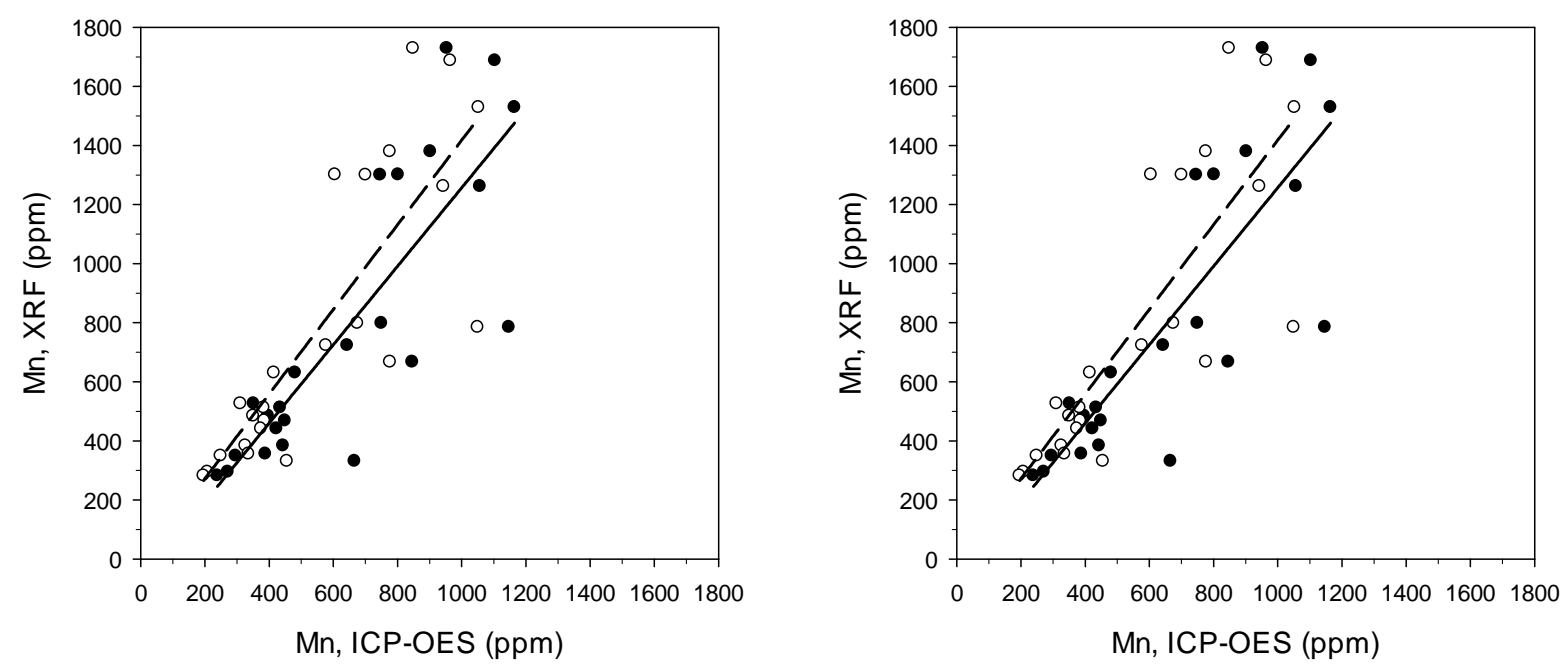

Figure 2. Soil Mn levels in a subset $(n=23)$ of soil samples from Valcamonica and Garda Lake. Left panel: Mn levels measured by the BCR extraction method and ICP-OES versus levels measured in the field using the portable XRF instrument; Filled symbols and solid line are near total BCR extractable Mn (sum BCR fractions 1 - 4, see Methods) vs Mn measured by XRF $(y=1.33 x-71.8, R=0.830, p<0.0001)$, while open symbols and dashed line are BCR chemically labile Mn (sum BCR fractions 1 and 2$)$ vs Mn by XRF $(y=1.43 x-14.7, R=0.826, p<0.0001)$. Right panel: near total BCR extractable Mn versus BCR chemically labile Mn $(y=0.9141 x-30.859, R=0.990, p<0.0001)$, both measured by ICP-OES.

Table 2. Concentrations of metals in lettuce (Lactuca sativa) sampled in the Valcamonica $(n=11)$ and Garda Lake $(n=12)$ gardens.

\begin{tabular}{cccccc}
\hline & \multicolumn{2}{c}{ Valcamonica } & \multicolumn{2}{c}{ Garda Lake } & $\mathrm{p}$ Value \\
\cline { 2 - 5 } & Median & Interquartile Range & Median & Interquartile Range & \\
\hline $\mathrm{Mn}(\mathrm{ppm})$ & 53.6 & $(37.65-66.65)$ & 30.15 & $(18.23-47.77)$ & 0.03918 \\
$\mathrm{Fe}(\mathrm{ppm})$ & 153.2 & $(140.3-220.4)$ & 117.9 & $(87.38-148.68)$ & 0.07935 \\
$\mathrm{Zn}(\mathrm{ppm})$ & 94.4 & $(65.4-110.95)$ & 83.45 & $(64.12-100.98)$ & 0.4984 \\
$\mathrm{Cu}(\mathrm{ppm})$ & 10 & $(7.1-13.45)$ & 12.85 & $(11.2-14.7)$ & 0.15691 \\
\hline
\end{tabular}

Table 3. Concentrations of metals in chicory (Chichorium spp.) sampled in the Valcamonica $(n=52)$ and Garda Lake $(n=14)$ gardens.

\begin{tabular}{cccccc}
\hline & \multicolumn{2}{c}{ Valcamonica } & Garda Lake & p Value \\
\cline { 2 - 5 } & Median & Interquartile Range & Median & Interquartile Range & 0.99374 \\
$\mathrm{Mn}(\mathrm{ppm})$ & 46.75 & $(31.35-63.67)$ & 42.6 & $(36.77-52.97)$ & 0.13212 \\
$\mathrm{Fe}(\mathrm{ppm})$ & 113.25 & $(92.12-153.32)$ & 92.55 & $(79.65-120.2)$ & 0.61571 \\
$\mathrm{Zn}(\mathrm{ppm})$ & 75.7 & $(53.07-96.5)$ & 71.05 & $(53.83-84.3)$ & 0.05562 \\
$\mathrm{Cu}(\mathrm{ppm})$ & 12 & $(7.55-18.4)$ & 19.4 & $(12.48-25.5)$ & \\
\hline
\end{tabular}

\section{Discussion}

This study addresses the possible consequences of historical emission of heavy metals from the ferroalloy industry on home gardens and grown vegetables in the province of Brescia, Italy. Eight years after the cessation of active emission from the ferroalloy plants, higher values of $\mathrm{Mn}, \mathrm{Pb}, \mathrm{Fe}$ and $\mathrm{Zn}$ are still found in the soil of home gardens situated in Valcamonica, where ferroalloy plants had been operating for about a century, compared een $\mathrm{Mn}$ to home gardens in the reference area of the Garda Lake.

The anthropogenic origin of these metals is supported by the finding of an inverse non-linear relationship between the soil levels of $\mathrm{Mn}$ and the distance from the point source (Figure 4). In addition, the difference between Mn concentration in surface and deeper soil increases as a function of metal concentration in surface soil, which is higher in the vicinity of the ferroalloy plant 


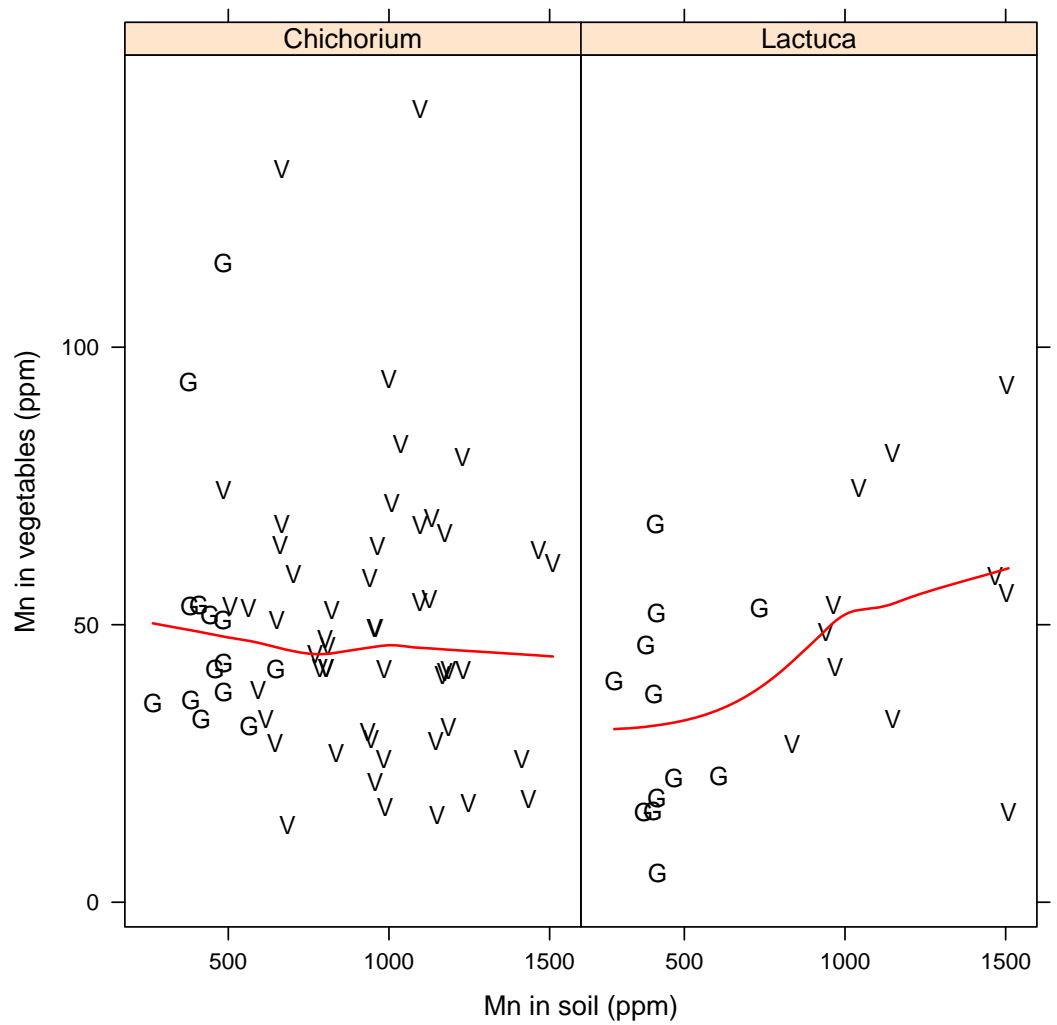

Figure 3. Association between $\mathrm{Mn}$ in soil and in the two types of salads, (V = Valcamonica, $\mathrm{G}=\mathrm{Garda}$ Lake).

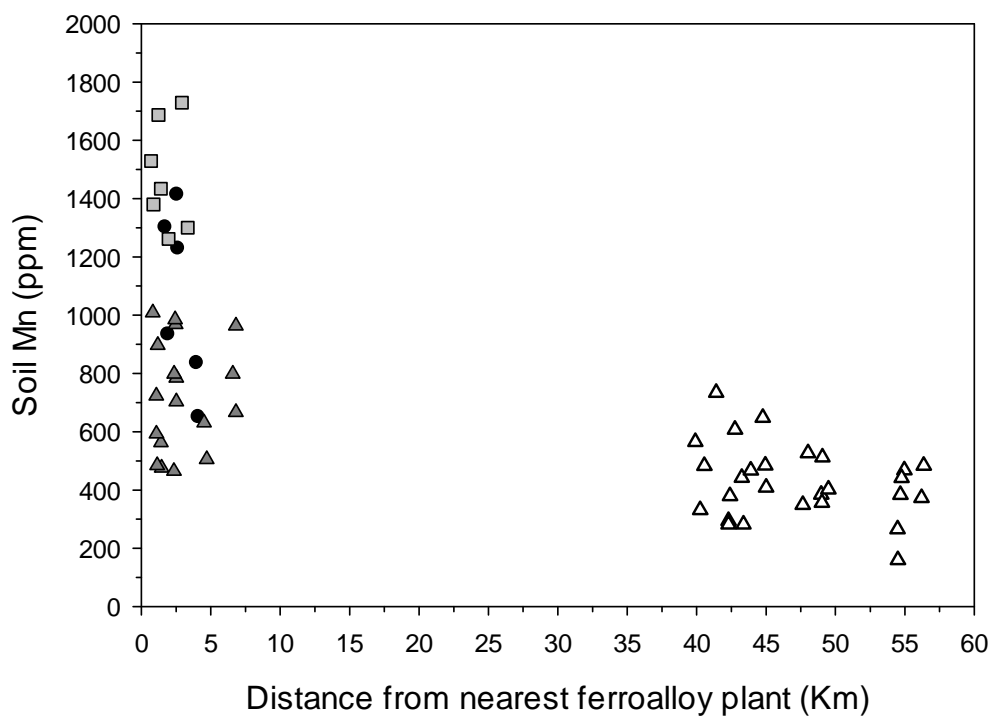

Figure 4. Concentrations of $\mathrm{Mn}$ in surface soil as a function of the distance from the point sources of the three ferroalloy plants of Breno (circles), Darfo (squares) and Sellero (filled triangles), Valcamonica. Distance for samples from the reference Garda Lake area (open triangles) were calculated relative to the closest ferroalloy plant, Sellero.

point sources (Figure 5). This finding supports deposition of metal emissions in the surface soil, according to a gradient from the point source, and confirms previous observations of higher levels in deposited dust from Valcamonica, as compared to the Garda Lake, and according to a similar spatial gradient from the point sources [17].
On-going surface deposition in Valcamonica is likely to occur as a result of re-suspended dusts that have been enriched in $\mathrm{Mn}$ and other metals from the prolonged historic activity of the ferroalloy plants. A minor contribution may also derive from continued active input from current emissions of one plant (Tassara in Breno) that was 


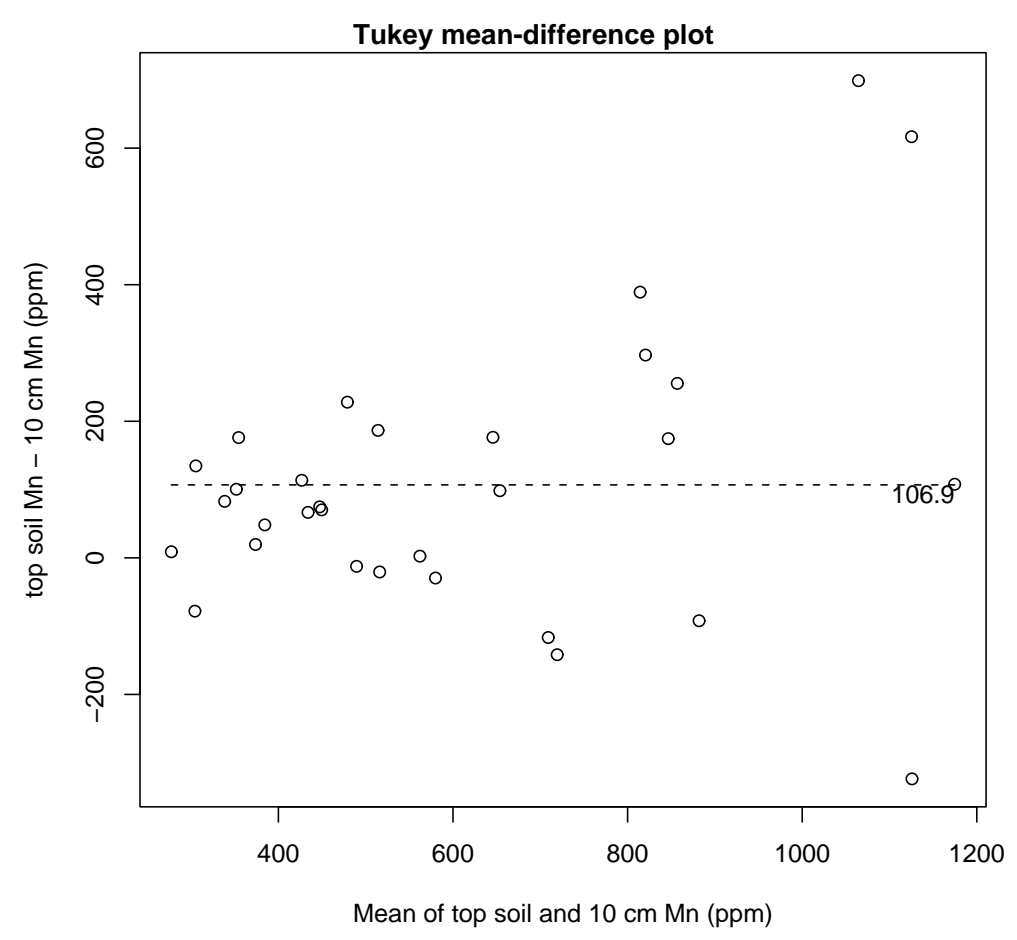

Figure 5. Increase of the difference between surface and deeper soil levels of Mn as a function of soil Mn in Valcamonica and Garda Lake (Tukey mean-difference plot).

converted to an iron smelter.

The levels of $\mathrm{Mn}, \mathrm{Fe}$, and $\mathrm{Zn}$ were higher in lettuce grown in Valcamonica, compared to the samples from the Garda Lake, whereas the concentrations of these metals in chicory did not differ between the two study sites. Based on the Mn data, the metal levels in lettuce better reflect the metal levels in soil than do metal levels in chicory. This is supported by the regression plots in Figure 5, though may be qualified by the limited data for lettuce compared to chicory. Lettuce has been reported as a hyper-accumulator of heavy metals [28] and of $\mathrm{Mn}$ in particular in regulated experimental conditions [7]. In our study chicory Mn levels, although not differing between the two areas, are not substantially lower than lettuce. The increased metal concentrations in lettuce from Valcamonica compared to the reference Garda Lake area reached statistical significance only for $\mathrm{Mn}$, though there were increasing trends for $\mathrm{Fe}$ and $\mathrm{Zn}$ in the lettuce from the Valcamonica region as well. In other words, the significant increase of $\mathrm{Mn}$ can be considered as plausible regardless of the small sample size, but the sample size may be too small to reject the null hypotheses for differences in concentrations for $\mathrm{Fe}$ and $\mathrm{Zn}$. The small sample size was in part determined by other factors of the study, namely that it was based on the presence of subjects within the larger epidemiological survey on the resident population in the target areas who also maintained a home garden. The family gardens were included based on the study participants and they differed in relation to the type of salad being cultivated.

The $\mathrm{Cu}$ content was higher in both vegetables and soil of the reference area of Garda Lake, and this may be due to the presence of vineyards in this area, where $\mathrm{Cu}$ is used in fungicide treatments against powdery mildew. The concentration of $\mathrm{Pb}$ in both lettuce and chicory was below the procedural detection limit, confirming that $\mathrm{Pb}$ transport from the soil to plants is extremely low [7, 29,30].

Limited information is available in the literature on soil background levels of heavy metals considered in this study. Natural background levels of total $\mathrm{Mn}$ in soil are generally reported with average values of $30-600 \mathrm{ppm}$ [31-36]. Concentrations of $\mathrm{Mn}$ in plants are reported between $10-100$ ppm [37]. Table 4 reports the most recent available data on metal concentrations in soil and lettuce, although direct comparison of these data is difficult because of the different analytical methods used in those studies. In the study by Itanna [38], $\mathrm{Mn}, \mathrm{Cu}$, and $\mathrm{Zn}$ in soil were determined using inductively coupled plasmamass spectrometry (ICP-MS) after external calibration and internal standardization. Ismail et al. [39] measured heavy metals in vegetables using atomic absorption spectrometry (AAS) following the standard additions method [40]. Regardless of potential analytical differences, the concentrations of heavy metals in salad measured in our study are comparable with the most recent studies listed in Table 4.

Our soil data instead are generally higher compared to 
Table 4. Average metal concentrations (ppm) in vegetables and soil reported in the literature (FAAS: Flame Atomic Absorption Spectroscopy; DP-ASV: Differential Pulse Anodic Stripping Voltammetry; ICP-OES: Inductively Coupled Plasma Optical Emission Spectrometry; AAS: Atomic Absorption Spectrophotometry; ICP-MS: Inductively Coupled Plasma Mass Spectrometry).

\begin{tabular}{|c|c|c|c|}
\hline Soil & Lettuce & Analytical methods & Reference \\
\hline \multirow[t]{2}{*}{$\begin{array}{l}\text { (Dry weight) } \\
\text { Cu: } 4.90 \pm 0.25 \\
\text { Mn: } 78.71 \pm 2.75 \\
\text { Zn: } 48.57 \pm 3.15\end{array}$} & $\begin{array}{l}\text { (Dry weight) } \\
\text { Cu: } 3.81 \pm 0.17 \\
\text { Mn: } 28.0 \pm 1.3 \\
\text { Zn: } 81.5 \pm 5.3\end{array}$ & ICP-OES & Pillay and Jonnalagadda (2007) \\
\hline & $\begin{array}{l}\text { (Dry leaves) } \\
\text { Cu: } 35.4 \pm 8.1 \\
\text { Mn: } 408 \pm 119 \\
\text { Zn: } 76.8 \pm 20.9\end{array}$ & AAS & Peris et al. (2007) \\
\hline $\begin{array}{l}\text { (Dry weight) } \\
\text { Unadulterated } \\
\text { Cu: } 11.3-20.9 \\
\text { Mn: } 45.3-65.0 \\
\text { Pb: } 6.3-12.5 \\
\text { Zn: } 8.7-17.7 \\
\text { Low spiked } \\
\text { Cu: } 170.7-336.3 \\
\text { Mn: } 381.9-572.8 \\
\text { Pb: } 22.6-33.2 \\
\text { Zn: } 93.5-181.7\end{array}$ & $\begin{array}{l}\text { (Dry leaves) } \\
\mathrm{Cu}: 2.4 \pm 0.2 \\
\text { Mn: } 114.3 \pm 9.8 \\
\mathrm{~Pb}: 0.2 \pm 0.2 \\
\mathrm{Zn}: 31.3 \pm 8.1 \\
\mathrm{Cu}: 13.5 \pm 2.2 \\
\mathrm{Mn}: 1246 \pm 162 \\
\mathrm{~Pb}: \mathrm{ND} \\
\mathrm{Zn}: 154.3 \pm 43.8\end{array}$ & $\begin{array}{l}\mathrm{Cu}, \mathrm{Mn}, \mathrm{Zn} \text { in soil: FAAS } \\
\mathrm{Cu} \text { in plants: DP-ASV } \\
\mathrm{Mn}, \mathrm{Zn} \text { in plants: FAAS }\end{array}$ & Intawongse and Dean (2006) \\
\hline $\begin{array}{l}\text { Mn: } 34.9 \pm 5.3 \\
\text { Cu: } 8.8 \pm 1.51 \\
\text { Zn: } 5.9 \pm 1.02\end{array}$ & $\begin{array}{l}\text { Mn: } 20.37 \\
\text { Cu: } 0.9 \\
\text { Zn: } 42\end{array}$ & AAS & Mohamed et al. (2003) \\
\hline \multirow[t]{2}{*}{$\begin{array}{l}\text { Cu: } 13.2 \pm 4.1 \\
\text { Mn: } 63 \pm 37 \\
\text { Zn: } 41.7 \pm 16.6\end{array}$} & $\begin{array}{l}\text { Kera } \\
\text { Cu: } 6.62 \\
\text { Mn: } 106.00 \\
\text { Zn: } 48.63 \\
\text { Peacok } \\
\text { Cu: } 6.24 \\
\text { Mn: } 54.00 \\
\text { Zn: } 47.80\end{array}$ & $\begin{array}{l}\text { Soil: ICP-MS } \\
\text { Lettuce: ICP-OES }\end{array}$ & Itanna (2002) \\
\hline & $\begin{array}{l}\text { (Dry weight) } \\
\text { Msimbazi river } \\
\text { Cu: } 0.25 \\
\text { Zn: } 1.48 \\
\text { Sinza river } \\
\text { Cu: } 0.58 \\
\text { Zn: } 1.59 \\
\end{array}$ & AAS & Bahemuka and Mubofu (1998) \\
\hline
\end{tabular}

the literature data, especially for those measured in Valcamonica area.

Few normative data are available for the concentration of $\mathrm{Mn}, \mathrm{Pb}, \mathrm{Fe}, \mathrm{Cu}$ and $\mathrm{Zn}$ in both soil and vegetables. The Italian regulation indicates normative soil values for Mn (750 - 1000 ppm), Pb (5 - 120 ppm), Cu (10 - 120 $\mathrm{ppm})$, and $\mathrm{Zn}(10-150 \mathrm{ppm})$ [18]. Normal Mn values $(30-200 \mathrm{ppm})$ and toxic or excessive Mn values (>300 ppm) for plant tissues are reported by OMAFRA (Ontario Ministry of Agriculture Food \& Rural Affairs) [41]. In any case, these values are not intended as protective for human health.

The level of $\mathrm{Mn}, \mathrm{Pb}, \mathrm{Fe}$ and $\mathrm{Zn}$ was higher in the garden soils of Valcamonica compared to those of the Garda Lake, and the level of $\mathrm{Mn}, \mathrm{Fe}$ and $\mathrm{Zn}$ was higher in lettuce from Valcamonica. On the other hand $\mathrm{Cu}$ was higher in soil and lettuce from the Garda Lake. Furthermore, we observed an association between the soil con- tent of total Mn and the concentration in the edible parts of lettuce. This implies that these elements can be transported from the soil to the plants, and that enrichment of these metals in soil due to ferroalloy plant activity may lead to increased human dietary exposure through contaminated vegetables.

The highly significant correlation between soil measurements by XRF versus ICP-OES supports that the XRF instrument is a good screening method for soil metal levels (Figure 2). Moreover, there were relatively consistent relationships between total soil metal levels measured by $\mathrm{XRF}$, near total metal levels measured by the BCR extraction and ICP-OES, and the chemically labile fraction of metals in soil by BCR and ICP-OES. This suggests that chemically labile fractions of metals in soil can be reliably estimated from total metal levels measured by XRF when these relationships are known. Further, while the chemically labile fractions of metals in soil (i.e., sum 
BCR fractions $1+2$ ) do not directly reflect metal bioavailability, metals that are chemically labile would be expected to reflect increased bioavailability as well, as noted above.

Direct uptake by plants of airborne particles can take place also through the leaf surface, though this pathway is likely to be of lesser importance than root uptake of metals from the soil [42]. According to Cowan [43] the relationship between the total amount and extractable fraction in soil for metals like Mn is generally quite weak in non-experimentally controlled conditions. The available fraction of soil $\mathrm{Mn}$ for plant uptake is also influenced by a number of parameters including soil physical-chemical conditions like organic matter and clay content, aeration, moisture, soil texture, loading rate, soil $\mathrm{pH}$, redox potential, cation exchange capacity (CEC), sulphate, carbonate and hydroxide, the presence of microorganisms, and metereological conditions (e.g., precipitation). In general, $\mathrm{Mn}$ binding and residence time in the soil is directly related to the clay and/or organic matter content and the $\mathrm{pH}$. Organic matter plays an important role in determining the fate of metals in soil by increasing the organically-complexed fraction of metals in the soil. Thus, soils containing high concentrations of organic matter contain lower relative fractions of bioavailable metals. Therefore, $\mathrm{Mn}$ can be immobilized in soil by binding to substances like fulvic or humic acids. Higher organic matter favours also the microbiological activity which can further decrease the availability of $\mathrm{Mn}$ : a class of bacteria that converts ammonium to nitrates also oxidizes $\mathrm{Mn}$ to less available manganic forms. Weather conditions affect Mn cycling, with excess rain increasing the availability through reduction of $\mathrm{Mn}$, whereas drought can increase the deficiency by oxidation of Mn [44].

The availability of $\mathrm{Mn}$ is inversely related to the soil $\mathrm{pH}$, while soil $\mathrm{pH}$ below 5.5 may be toxic to plants, whereas soil $\mathrm{pH}$ above 6.5 may cause a metal deficiency condition. The valence state of $\mathrm{Mn}$ varies from $2\left(\mathbf{M n}^{2+}\right)$ to $7\left(\mathbf{M n}^{7+}\right)$, and the most common forms in soil are $\mathbf{M n}^{2+}$ and $\mathbf{M n}^{\mathbf{4}^{+}}$. At lower $\mathrm{pH}$ values, the manganous form $\mathbf{M n}^{2+}$ is prevalent and more readily available for plants. At higher $\mathrm{pH}$, the manganic form $\mathbf{M n}^{3,4-7+}$ are prevalent and less available for plants. The soil $\mathrm{pH}$ results were higher than 7 in both areas, Valcamonica and the Garda Lake, and therefore metals would be expected to be less soluble and bioavailable in these soil conditions compared to conditions of lower $\mathrm{pH}$. Regardless of the high $\mathrm{pH}$ values, our findings are consistent with increased levels of metals in lettuce caused by metal deposition in soil and the consequent uptake by the plants. It is noteworthy that measurements of metals in plants were done after a careful laboratory rinsing procedure to eliminate surficial contamination, which is not usually followed by consumers. Further work will be developed to compare the decrease of metal concentrations from nonwashed vegetables to normally washed, as well as after rigorous laboratory rinsing.

This will yield practical information about how to prevent possible excess of metals in salad.

\section{Conclusions}

The results of this study are consistent in showing increased levels of heavy metals including $\mathrm{Mn}, \mathrm{Pb}, \mathrm{Fe}$ and $\mathrm{Zn}$ in local home garden soil and lettuce from gardens located in the vicinities of formerly active ferroalloy plants.

These increased metal levels are attributed to historical emissions and possible re-suspension/re-deposition of particles enriched in metals from ferroalloy plant activity.

We observed an inverse non-linear relationship between the soil levels of $\mathrm{Mn}$ and the distance from the point source and a significant association between the near total BCR extractable metal levels (sum fractions 1 -4) and the chemically (and likely biologically) labile metals fractions (BCR fractions $1+2$ ) that highlights the anthropogenic origin of $\mathrm{Mn}$ in soils from the Valcamonica study site

In addition, a positive association was observed between the Mn concentrations in soil and in the edible part of lettuce, but not chicory, grown from the same soils. This indicates lettuce Mn levels better reflect levels in soil, and that enrichment of Mn in soil due to ferroalloy plant activity may lead to increased human dietary exposure through contaminated vegetables.

The concentrations of metals in the vegetables observed in our study were below hazardous levels of acute toxicity to the plants. This is probably due to the $\mathrm{pH}$ values in the local soils, which may have reduced availability of these metals by hampering their degree of solubility and uptake by plants. Therefore, the vegetables grown in these areas should be considered as relatively safe from the standpoint of possible acute health implications. Nevertheless, possible long term negative effects cannot be excluded and will be considered in future epidemiological and experimental studies in this region.

\section{Acknowledgements}

This study was supported by funding from the European Union through its Sixth Framework Programme for RTD (Contract No. FOOD-CT-2006-016253). It reflects only the authors' views, and the European Commission is not liable for any use that may be made of the information contained therein.

The project described was supported also by Award Number R01ES019222 from the National Institute of Environmental Health Sciences. The content is solely the 
responsibility of the authors and does not necessarily represent the official views of the National Institute of Environmental Health Sciences or the National Institutes of Health.

\section{REFERENCES}

[1] M. Muller and M. Anke, "Distribution of Cadmium in the Food Chain (Soil-Plant-Human) of a Cadmium Exposed Area and the Health Risks of the General Population," Science of the Total Environment, Vol. 156, No. 2, 1994, pp. 151-159. doi:10.1016/0048-9697(94)90352-2

[2] H. T. Davis, C. M. Aelion, S. McDermott and A. B. Lawson, "Identifying Natural and Anthropogenic Sources of Metals in Urban and Rural Soils Using GIS-Based Data, PCA, and Spatial Interpolation," Environmental Pollution, Vol. 157, No. 8-9, 2009, pp. 2378-2385. doi:10.1016/j.envpol.2009.03.021

[3] C. M. Aelion, H. T. Davis, S. McDermott and A. B. Lawson, "Metal Concentrations in Rural Topsoil in South Carolina: Potential for Human Health Impact," Science of the Total Environment, Vol. 402, No. 2-3, 2008, pp. 149156. doi:10.1016/j.scitotenv.2008.04.043

[4] Y. Liu, S. McDermott, A. Lawson and C. M. Aelion, "The Relationship between Mental Retardation and Developmental Delays in Children and the Levels of Arsenic, Mercury and Lead in Soil Samples Taken near Their Mother's Residence during Pregnancy," International Journal of Hygiene and Environmental Health, Vol. 213, No. 2, 2010, pp. 116-123. doi:10.1016/j.ijheh.2009.12.004

[5] S. M. Reichman, "The Responses of Plants to Metal Toxicity: A Review Focusing on Copper, Manganese and Zinc," Australian Minerals \& Energy Environment Foundation, Published as Occasional Paper No. 14, 2010. http://www.plantstress.com/Articles/toxicity_i/Metal_toxi city.pdf

[6] Y. J. Cui, Y.-G. Zhu, R. H. Zhai, Y. Z. Huang, Y. Qiu and J. Z. Liang, "Exposure to Metal Mixtures and Human Health Impacts in a Contaminated Area in Nanning, China," Environment International, Vol. 31, No. 6, 2005, pp. 784790. doi:10.1016/j.envint.2005.05.025

[7] M. Intawongse and J. R. Dean, "Uptake of Heavy Metals by Vegetable Plants Grown on Contaminated Soil and Their Bioavailability in the Human Gastrointestinal Tract," Food Additives \& Contaminants, Vol. 23, No. 1, 2006, pp. 36-48. doi:10.1080/02652030500387554

[8] M. J. Mc Laughlin, D. R. Parker and J. M. Clarke, "Metals and Micronutrients-Food Safety Issues," Field Crops Research, Vol. 60, No. 1-2, 1999, pp. 143-163. doi:10.1016/S0378-4290(98)00137-3

[9] S. Clemens, M. G. Palmgren and U. Krämer, "A Long Way Ahead: Understanding and Engineering Plant Metal Accumulation," Trends in Plant Science, Vol. 7, No. 7, 2009, pp. 309-315. doi:10.1016/S1360-1385(02)02295-1

[10] A. R. Memon and P. Schröder, "Metal Accumulation in Plants and Its Implication in Phytoremediation," Environmental Science Pollution, Vol. 16, No. 2, 2009, pp. 162-175.
[11] D. R. Sauerbeck, "Uptake and Availability of Heavy Metals," Water Air Soil Pollution, Vol. 57-58, No. 1, 1991, pp. 227-237. doi:10.1007/BF00282886

[12] P. S. Hooda, "Plant Availability of Heavy Metals in Soils Previously Amended with Heavy Applications of Sewage Sludge," Journal of the Science of Food Agriculture, Vol. 73, No. 4, 1997, pp. 446-454. doi:10.1002/(SICI)1097-0010(199704)73:4<446::AID-JS FA749>3.0.CO;2-2

[13] G. P. Cobb, K. Sands, M. Waters, B. G. Wixson and E. Dorward-King, "Accumulation of Heavy Metals by Vegetables Grown in Mine Wastes," Environmental Toxicology and Chemistry, Vol. 19, No. 3, 2000, pp. 600-607. doi:10.1002/etc.5620190311

[14] D. M. Zhou, X. Z. Hao, Y. J. Wang, Y. H. Dong and L. Cang, "Copper and Zn Uptake by Radish and Pakchoi as Affected by Application of Livestock and Poultry Manures," Chemosphere, Vol. 59, No. 2, 2005, pp. 167-175. doi:10.1016/j.chemosphere.2004.11.008

[15] WHO, "Environmental Health Criteria 17. Manganese," World Health Organization, Geneva, 1981.

[16] R. Lucchini, E. Albini, L. Benedetti, S. Borghesi, R. Coccaglio, E. Malara, G. Parrinello, S. Garattini, S. Resola and L. Alessio, "High Prevalence of Parkinsonian Disorders Associated to Manganese Exposure in the Vicinities of Ferroalloy Industries," American Journal of Industrial Medicine, Vol. 50, No. 11, 2007, p. 788. doi:10.1002/ajim.20494

[17] L. Borgese, A. Zacco, S. Pal, E. Bontempi, R. G. Lucchini, N. J. Zimmerman and L. E. Depero, "A New Non-Destructive Method for Chemical Analysis of Particulate Matter Filters: The Case of Manganese Air Pollution in Vallecamonica (Italy)," Talanta, Vol. 84, No. 1, 2011, pp. 192-198. doi:10.1016/j.talanta.2010.12.048

[18] R. Lucchini, S. Guazzetti, S. Zoni, F. Donna, S. Peter, A. Zacco, M. Salmistraro, E. Bontempi, N. J. Zimmerman and D. R. Smith, "Tremor, Olfactory and Motor Changes in Italian Adolescents Exposed to Historical Ferro-Manganese Emission," Neurotoxicology, 2012, in press. doi:10.1016/j.neuro.2012.01.005

[19] A. Zacco, S. Resola, R. Lucchini, E. Albini, N. Zimmerman, S. Guazzetti and E. Bontempi, "Analysis of Settled Dust with X-Ray Fluorescence for Exposure Assessment of Metals in the Province of Brescia, Italy," Journal of Environmental Monitoring, Vol. 11, 2009, pp. 1579-1985. doi:10.1039/b906430c

[20] Ministerial Decree, "Official Methods for Soil Chemical Analysis D.M. n. 185," Rome, September 13, 1999.

[21] Ph. Quevauviller, G. Rauret, J.-F. López-Sánchez, R. Rubio, A. Ure and H. Muntau, "Use of a Certified Reference Material for Extractable Trace Metals to Assess Sources of Uncertainty in the BCR Three Stage Sequential Extraction Procedure," Analytica Chimica Acta, Vol. 382, No. 3, 1999, pp. 317-327. doi:10.1016/S0003-2670(98)00754-5

[22] G. Rauret, J. F. Lopez-Sanchez, A. Sahuquillo, E. Barahona, M. Lachica, A. M. Ure, C. M. Davidson, A. Gomez, J. Bacon, M. Yli-Halla, H. Mautau and P. Quevauviller, "Application of a Modified BCR Sequential Extraction (ThreeStep) Procedure for the Determination of Extractable 
Trace Metal Contents in a Sewage Sludge Amended Soil Reference Material (CRM 483), Complemented by a Three Year Stability Study of Acetic Acid and EDTA Extractable Metal Content," Journal of Environmental Monitoring, Vol. 2, No. 3, pp. 228-233. doi:10.1039/b001496f

[23] K. F. Mossop and C. M. Davidson, "Comparison of Original and Modified BCR Sequential Extraction Procedures for the Fractionation of Copper, Iron, Lead, Manganese, and Zinc in Soils and Sediments," Analytica Chimica Acta, Vol. 478, No. 1, 2003, pp. 111-118. doi:10.1016/S0003-2670(02)01485-X

[24] E. Bontempi, A. Zacco, D. Benedetti, L. Borgese, P. Colombi, H. Stosnach, G. Finzi, P. Apostoli, P. Buttini and L. E. Depero, "Total Reflection X-Ray Fluorescence (TXRF) for Direct Analysis of Aerosol Particle Samples," Environmental Technology, Vol. 31, No. 5, 2010, pp. 467477. doi:10.1080/09593330903513260

[25] F. J. Antosz, Y. Q. Xiang, A. R. Diaz and A. J. Jensen, "The Use of Total Reflectance X-Ray Fluorescence (TXRF) for the Determination of Metals in the Pharmaceutical Industry," Journal of Pharmaceutical and Biomedical Analysis, Vol. 62, 2012, pp. 17-22. doi:10.1016/j.jpba.2011.12.020

[26] L. Borgese, A. Zacco, E. Bontempi, P. Colombi, R. Bertuzzi, E. Ferretti, S. Tenini and L. E. Depero, "Total Reflection of X-Ray Fluorescence (TXRF): A Mature Technique for Environmental Chemical Nanoscale Metrology," Measurement Science and Technology, Vol. 20, No. 8, 2009, Article ID 084027. doi:10.1088/0957-0233/20/8/084027

[27] "R Development Core Team, R Foundation for Statistical Computing," Vienna, 2009.

[28] US Department of Energy, Office of Environmental Management, "Empirical Models for the Uptake of Inorganic Chemicals from Soil by Plants," 1998.

[29] K. Chojnacka, A. Chojnacki, H. Gorecka and H. Gorecki, "Bioavailability of Heavy Metals from Polluted Soils to Plants," Science of the Total Environment, Vol. 337, No. 1-3, 2005, pp. 175-182. doi:10.1016/j.scitotenv.2004.06.009

[30] Y. J. Cui, Y.-G. Zhu, R. H. Zhai, Y. Z. Huang, Y. Qiu and J. Z. Liang, "Transfer of Metals from Soil to Vegetables in an Area near a Smelter in Nanning, China," Environment International, Vol. 30, No. 6, 2004, pp. 785-791. doi:10.1016/j.envint.2004.01.003

[31] H. T. Shacklette, J. C. Hamilton, J. G. Boerngen and J. M. Bowles, "Elemental Composition of Surficial Materials in the Coterminous United States," US Geological Survey, Washington DC, 1971, Professional Paper 574-D.
[32] W. C. Cooper, "The Health Implications of Increased Manganese in the Environment Resulting from the Combustion of Fuel Additives: A Review of the Literature," Journal of Toxicology and Environmental Health, Vol. 14, No. 1, 1984, pp. 23-46. doi:10.1080/15287398409530561

[33] D. C. Adriano, "Trace Elements in the Terrestrial Environment," Springer-Verlag, New York, 1986.

[34] W. H. Schroeder, M. Dobson and D. M. Kane, "Toxic Trace Elements Associated with Airborne Particulate Matter: A Review," Journal of the Air Pollution Control Association, Vol. 37, 1987, pp. 1267-1285.

[35] W. P. Eckel and W. D. Langely, "A Background-Based Ranking Technique for Assessment of Elemental Enrichment in Soils at Hazardous Waste Sites," Proceedings of the 9th National Conference, Silver Spring, Hazardous Materials Control Research Institute, Washington DC, 1988, pp. 282-286.

[36] S. K. Rope, W. J. Arthur, T. H. Craig and E. H. Craig, "Nutrient and Trace Elements in Soil and Desert Vegetation of Southern Idaho," Environmental Monitoring and Assessment, Vol. 10, No. 1, 1988, pp. 1-24. doi:10.1007/BF00394252

[37] M. N. V. Prasad and J. Hagemeyer, "Heavy Metal Stress in Plants, from Molecules to Ecosystems," Springer-Verlag, Berlin, 1999, pp. 51-71.

[38] F. Itanna, "Metals in Leafy Vegetables Grown in Addis Ababa and Toxicological Implications," The Ethiop Journal of Health Development, Vol. 16, 2002, pp. 295-302.

[39] B. S. Ismail, K. Farihah and J. Khairiah, "Bioaccumulation of Heavy Metals in Vegetables from Selected Agricultural Areas," Bulletin of Environmental Contamination and Toxicology, Vol. 74, No. 2, 2005, pp. 320-327. doi:10.1007/s00128-004-0587-6

[40] AOAC, "Official Method of Analysis Association of Official Chemists," 14th Edition, Sidney Williams., Inc. Virginia, 1984.

[41] K. Callow, "Know Your Micros before You Apply,” 2010. http://www.omafra.gov.on.ca/english/crops/hort/news/hor tmatt/2003/14hrt03a3.htm

[42] M. I. Sheppard and D. H. Thibault, "Natural Uranium Concentrations of Native Plants over a Low-Grade Ore Body," Soil Science Society of American Journal, Vol. 56, No. 2, 1992, pp. 415-423. doi:10.2136/sssaj1992.03615995005600020012x

[43] D. Cowan, "Manganese, Measure and Manage," Agri-Food Laboratories CCA, 2005.

[44] D. Cowan, "Plant Sampling and Testing Information, Measure and Manage," Agri-Food Laboratories CCA, 2005. 